\title{
A Case Study on the Assessment of Program Quality through CO-PO Mapping and its Attainment
}

\author{
B. Rajagopal Reddy ${ }^{1}$, Natarajan Karuppiah ${ }^{2}$, Md. Asif ${ }^{3}$, S. Ravivarman ${ }^{4}$ \\ 1,3 Associate Professor, Vardhaman College of Engineering Hyderabad \\ ${ }^{2,4}$ Professor, Vardhaman College of Engineering Hyderabad \\ ${ }^{1}$ b.rajagopalreddy@vardhaman.org \\ ${ }^{2}$ natarajankaruppaih@gmail.com \\ 3asif_eee@rediffmail.com \\ ${ }^{4}$ ravivarman@vardhaman.org
}

\begin{abstract}
In recent years, accreditation of National Board of Accreditation has become mandatory for all the Autonomous colleges and Universities. NBA stresses on Outcome Based Education to improve the quality of education. It has formulated twelve graduate attributes to measure the quality of the program that a graduate has to acquire from any college/university during his four years of under graduation. The success of any program depends on the attainment of course outcomes and program outcomes. But there is a lack of understanding among the Engineering faculties in CO-PO attainment calculations. This study explores the significance of proper $\mathrm{CO}-\mathrm{PO}$ mapping and its attainment calculation. CO-PO mapping and its attainment calculations are an integral part of OBE and it helps in continuous quality improvement, which serves as a feedback for OBE loop. CQI is instrumental in identifying any setbacks in Teaching Learning Process and additional solutions are figured out to improve the delivery of the course. In this study, different approaches are suggested to calculate the attainment of COs of the course and POs, PSOs of the program. Results and discussions are done on the attainment of COs of different courses and suggestions for the courses which fail to attain the target has been discussed. A sample of CO-PO attainment calculation for the course Basic Electrical Engineering offered for BTech I Year students has been discussed. Microsoft Office Excel spreadsheet has been used for computation purpose.
\end{abstract}

Keywords: National Board of Accreditation, Course Outcome, Program Outcome, Outcome Based Education, Continuous Quality Improvement

\section{Corresponding Author}

B. Rajagopal Reddy, Associate Professor, Vardhaman

College of Engineering Hyderabad

b.rajagopalreddy@vardhaman.org

\section{INTRODUCTION}

The Outcome Based Education (OBE) is adopted by AICTE from Washington Accord on 13 June 2014[1,2]. Outcome-based education (OBE) in engineering colleges across the world is a major change that various technical and academic institutions. OBE is outcome-based learning in which the engineering graduates are trained to have better knowledge, skill sets and attitudes. In OBE certain targets are set and teaching learning activities are properly planned and organized to achieve the targets. According to OBE system, the NBA's parameters called Graduate Attributes [3,5] must reflect on a graduate of an engineering program. OBE is an educational process that involves the restructuring of curriculum, assessment methods, and reporting practices in education to reflect a better learning and improving the skills with additional supporting qualities of an engineering graduate instead of accumulating the credits. This approach demands a positive change in the teaching and assessment methods of teaching faculty of academic institutions. Various researchers have discussed the implementation of OBE model $[4,10,11,12]$. Different assessment and attainment methods of course outcomes (COs) and program outcomes (POs) for NBA Tier II accreditation in engineering colleges through OBE are discussed $[7,8,9]$.

In this paper, assessment of program quality through $\mathrm{CO}$ PO mapping and attainment of COs of the course and POs, PSOs of the program is presented. The following sections give brief description of paper. Section 2 presents process of outcome-based assessment. CO-PO attainment methodology is explained in Section 3. Section 4 explains computations of attainment of $\mathrm{COs}$ of Basic Electrical Engineering (BEE) course. Section 5 discusses about COPO mapping methodology. Computations of attainment of POs/PSOs with BEE course are discussed in section 6 . Continuous quality improvement and conclusion remarks are discussed in sections $7 \& 8$ respectively.

\section{OUTCOME BASED ASSESSMENT}

Outcome Based Assessment (OBA) is the process of gathering information about how well a student is achieving specific outcomes. It is a systematic and ongoing process of collecting, interpreting, and acting on information relating to the goals and outcomes developed to support the department and institution's mission and vision. The assessment process is depicted in the Fig. 1. 


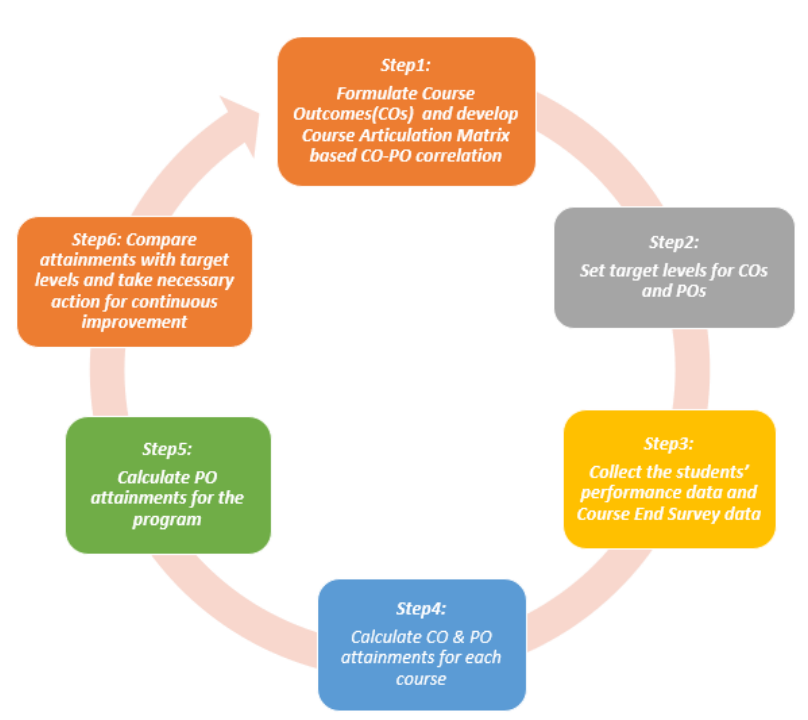

Fig. 1 Outcome Based Assessment Process

\section{A. Develop Course Outcomes}

The first step in the process of assessment is the formulation of course outcomes. Each subject is referred to as a course in NBA and its outcomes are framed by the course lead and the other course coordinators. These course outcomes are presented before an expert panel consisting of HOD, Professors and senior academicians. These course outcomes are shaped up to a final draft based on the comments of the expert panel. Once the course outcomes are formulated then the process of measuring these outcomes should be specified. Various methods of assessment are followed to measure these course outcomes. The various types of assessment methods are briefly explained below.

\section{B. Identify Methods of Measuring COs}

1) Formative Assessment: Formative assessment is taken from the students at varying intervals throughout the course. Formative assessment is a process of evidence gathering about the students' learning progress and performance. Formative assessment has the scope of guiding the instructors in such a way to meet the students learning needs and to make them regulators of their own learning. The following are various assessment tools used to assess the students' learning progress and performance. Cumulative Internal Examinations are used in Formative Assessment. The formative assessment pattern for different courses is shown in Table 1.

Table 1. Formative Assessment pattern for different courses

\begin{tabular}{|l|c|c|c|c|}
\hline \multicolumn{1}{|c|}{$\begin{array}{c}\text { Type of } \\
\text { Course }\end{array}$} & CAT1 & CAT2 & AAT & Practice \\
\hline $\begin{array}{l}\text { Integrated } \\
\text { Course }\end{array}$ & $\checkmark$ & $\checkmark$ & $\checkmark$ & $\checkmark$ \\
\hline $\begin{array}{l}\text { Theory } \\
\text { Course }\end{array}$ & $\checkmark$ & $\checkmark$ & $\checkmark$ & \\
\hline Practical & & & & $\checkmark$ \\
\hline
\end{tabular}

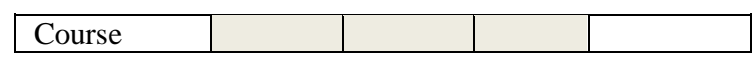

Integrated courses are the one which has a fine blend of theory and practical. Course content is designed in such a way that the student will have a chance to study most of the theoretical concepts by realising it in laboratories. In other words, practice-based learning is facilitated in integrated courses.

CAT: (Continuous Assessment Test) Two CAT tests shall be conducted one in the middle of the semester and the other at the end of the semester.

AAT:(Alternate Assessment Test) It is used by the respective course instructor by defining the assessment methods well before the commencement of the course. The formative assessment pattern for internship and project work is shown in Table 2.

Table 2. Formative Assessment pattern for Internship and Project work

\begin{tabular}{|l|c|c|c|}
\hline $\begin{array}{l}\text { Type of } \\
\text { Course }\end{array}$ & Review1 & Review2 & Viva-Voce \\
\hline Internship & $\checkmark$ & $\checkmark$ & $\checkmark$ \\
\hline Mini-Project & $\checkmark$ & $\checkmark$ & $\checkmark$ \\
\hline Project Work & $\checkmark$ & $\checkmark$ & $\checkmark$ \\
\hline
\end{tabular}

Internship, Min Project and Project Work assessment is based on two reviews and viva voce.

2) Summative Assessment: Summative assessment is used to evaluate student learning, skill acquisition and academic achievement at the conclusion of a defined instructional period. This assessment is taken by students at the end of the semester to demonstrate the "sum" of what they have or have not learnt. Summative assessment is a process of evidence gathering about the students' learning progress and performance through Semester End Examination (SEE).

3) Assessment Analysis: Course Outcomes of all courses of the program and Program Outcomes are measured by using two assessment methods such as Direct Assessment and Indirect Assessment. The weightage for direct assessment is $90 \%$ and indirect assessment is $10 \%$.

4) Direct Assessment: For Course Outcomes attainment, Direct Assessment includes Cumulative Internal Examination (CIE) and Semester End Examination (SEE). CIE is measured based on formative assessment whereas SEE is measured based on summative assessment. Weightage of each examination is shown below in Table 3.

Table 3. Weightage of CIE and SEE

\begin{tabular}{|l|l|l|}
\hline \multicolumn{3}{|c|}{ Direct Assessment } \\
\hline 1. & $\begin{array}{l}\text { Cumulative Internal } \\
\text { Examination (CIE) }\end{array}$ & $30 \%$ \\
\hline 2. & $\begin{array}{l}\text { Semester End Examination } \\
\text { (SEE) }\end{array}$ & $70 \%$ \\
\hline
\end{tabular}

For Program Outcomes attainment (POs), the prescribed POs by NBA are classified as technical POs and nontechnical POs. The first five POs and two formulated PSOs 
are called technical POs and remaining POs are called nontechnical POs. The Integrated courses and theory courses cumulatively contribute for the PO attainment of a batch. These technical POs and PSOs attainment are calculated by adding the contribution level of Integrated and theory courses to each PO and PSO. The attainment level of nontechnical POs is calculated using the active student participation in co-curricular and extra- curricular activities within and outside the college along with the contribution of Integrated and theory courses.

5) Indirect Assessment: For Course Outcomes attainment (COs), indirect assessment includes Course End Survey (CES), which is conducted on COs of each course at the end of the course in on-line mode. For Program Outcomes attainment (POs), indirect assessment has three components and they are:
1. Student Exit Survey (SES)
2. Co-Curricular Activities (CCA)
3. Extra-Curricular Activities (ECA)

Student Exit Survey (SES) is conducted on Program Outcomes (POs) and Program Specific Outcomes (PSOs) at the end of the program in on-line mode. Student exit survey is used in attainment calculation of both Technical and Non-Technical POs where as Co-Curricular Activities and Extra-Curricular Activities are used only in attainment calculation of Non-Technical POs.

\section{CO And PO AtTainment Methodology}

The calculation of CO \& PO attainments is based on the performance of the students in all assessments conducted in the course. The procedure to calculate $\mathrm{CO} \& \mathrm{PO}$ attainments is given below.

- Step1: Formulate appropriate Course Outcomes (COs) around 4 to 6 and develop Course Articulation Matrix based CO-PO correlation

- Step2: Set target levels for COs and POs

- Step3: Collect the students' performance data and Course Exit Survey data.

- Step4: Calculate CO \& PO attainments for each course based on direct and indirect assessments

- Step5: Use PO attainments of each course, student exit survey, co-curricular and extra-curricular activities data to calculate PO attainments for the program

- Step6: Compare attainments with target levels and take necessary action for continuous improvement

\section{CO Attainment Computations of BEE Course}

$\mathrm{CO}$ attainment computations of Basic Electrical Engineering course of BTech I semester is presented here. The basic information of the course is given in Table 4 .

Table 4: Basic Information of Course

\begin{tabular}{|l|l|l|l|}
\hline $\begin{array}{l}\text { ACADEMIC } \\
\text { YEAR: }\end{array}$ & $2019-20$ & BATCH: & $2018-2022$ \\
\hline REGULATION: & VCE R18 & PROGRAM: & B.Tech EEE \\
\hline $\begin{array}{l}\text { COURSE } \\
\text { NAME: }\end{array}$ & $\begin{array}{l}\text { Basic Electrical } \\
\text { Engineering }\end{array}$ & COURSE CODE: & A4203 \\
\hline YEAR \& SEM: & I YEAR \& I SEM & COURSE LEAD: & $\begin{array}{l}\text { MR. B. } \\
\text { RAJAGOPAL } \\
\text { REDDY }\end{array}$ \\
\hline COURSE TYPE: INTEGRATED & $\begin{array}{lll}\text { DESIGNATION } \\
\text { DEPARTMENT: }\end{array}$ & $\begin{array}{l}\text { ASSOCIATE } \\
\text { PROFESSOR/ } \\
\text { EEE }\end{array}$ \\
\hline
\end{tabular}

A. Mapping of COs in Formative Assessment

CAT1 and CAT2 are Continuous Assessment Tests 1 and 2 which is conducted at the end of first two units and the remaining three units respectively. The questions from CAT1 and CAT2 mapped with the corresponding COs. AATs and Lab sessions are also mapped with the corresponding COs. Questions fall under corresponding COs in formative Assessment are given in Table 5.

Table 5. Questions fall under corresponding COs in Formative Assessment

\begin{tabular}{|c|c|c|c|c|}
\hline $\mathrm{CO} \#$ & CAT1 & CAT2 & AAT & PRACTICE \\
\hline A4203.1 & Q2a, Q2b & Q3b & $\begin{array}{c}\text { AAT1, AAT2, } \\
\text { AAT3 }\end{array}$ & DDE, LT, FLE \\
\hline A4203.2 & Q1a, Q3a & & AAT1, AAT2 & DDE, LT, FLE \\
\hline A4203.3 & & $\begin{array}{l}\text { Q1b, Q2a, } \\
\text { Q2b }\end{array}$ & AAT1 & \\
\hline A4203.4 & Q1b, Q3b & Q1a, Q3a & АAT3 & DDE, LT, FLE \\
\hline A4203.5 & & & AAT1 & DDE, LT, FLE \\
\hline $\begin{array}{l}\text { AAT1: Team } \\
\text { Based } \\
\text { Assignments }\end{array}$ & $\begin{array}{c}\text { AAT2: } \\
\text { Remedial } \\
\text { Test }\end{array}$ & $\begin{array}{c}\text { AAT3: } \\
\text { Online Quiz }\end{array}$ & $\begin{array}{c}\text { DDE: Day-to- } \\
\text { Day } \\
\text { Evaluation }\end{array}$ & LT: Lab Test \\
\hline $\begin{array}{l}\text { FLE: Final } \\
\text { Lab Exam }\end{array}$ & & & & \\
\hline
\end{tabular}

Target for each $\mathrm{CO}$ is defined as " $\underline{65 \%}$ of students getting more than or equal to $60 \%$ (Academic Threshold) of marks (Set by the Program)". The actual marks secured by each student for each CO in CIE (Formative Assessment), AAT and practice are recorded and tabulated for each $\mathrm{CO}$ as shown in Fig. 2. The CO contribution of each student is computed based on assessment tool and their performance when compared with total marks is also recorded. Number of students who have contributed more than $60 \%$ marks for each $\mathrm{CO}$ is calculated with respect to the actual number of 
students contributed for that particular CO. This is $\mathrm{CO}$ attainment for a particular $\mathrm{CO}$ through CIE.

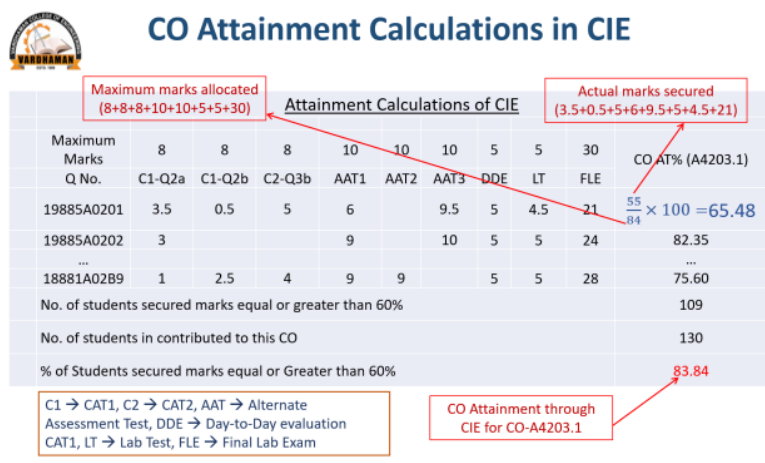

Fig. 2 CO Attainments through CIE

B. Mapping of COs in Summative Assessment

Summative Assessment refers to Semester End Examination and the questions from this assessment are mapped to the corresponding COs are shown in Table 6.

Table 6. Questions fall under corresponding COs in Summative Assessment

\begin{tabular}{|c|c|}
\hline CO\# & SEE \\
\hline A4203.1 & Q1a \\
\hline A4203.2 & $\begin{array}{r}\text { Q1b, Q1d, Q1g, Q2a, Q2b, } \\
\text { Q3c }\end{array}$ \\
\hline A4203.3 & $\begin{array}{r}\text { Q1c, Q1h, Q31, Q3b, Q3d, Q4b } \\
\text { Q4a, }\end{array}$ \\
\hline A4203.4 & $\begin{array}{r}\text { Q1f, Q5a, Q5b, Q5c, Q5d } \\
\text { A4203.5 }\end{array}$ \\
\hline
\end{tabular}

Target for each CO is defined as " $\underline{65 \%}$ (Target) of students getting more than or equal to $\underline{60 \%}$ (Academic Threshold) of marks (Set by the Program)". Form a team of experts to decide the Performance Threshold and Target. Target is usually decided based on previous results of the course. Performance Threshold can be same for entire institute; however, Target can be varied for each program.

The actual marks secured by each student for each $\mathrm{CO}$ in SEE tabulated as shown in Fig. 3. The CO contribution of each student is computed and their performance when compared with total marks is also recorded. Number of students who have contributed more than $60 \%$ marks for each $\mathrm{CO}$ is calculated with respect to the actual number of students contributed for that particular CO. This is $\mathrm{CO}$ attainment for a particular CO through SEE.

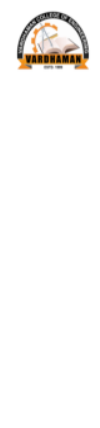

\section{CO Attainments Calculations for SEE}

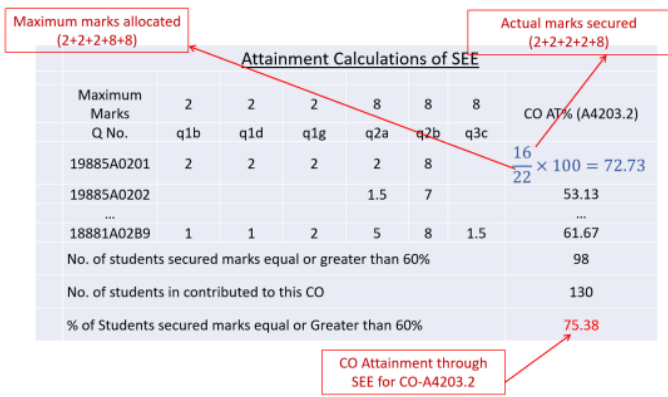

Fig. 3 CO Attainments through SEE

C. Indirect Assessment for CO Attainments

At the end of each course students will give feedback on each PO which is termed as Course End Survey(CES).

The $\mathrm{CO}$ attainments are computed based on weightages assigned for CIE, SEE and Direct Assessment, Indirect Assessment of the course. Total CO attainments of BEE course are shown in Fig. 4. The comparison of $\mathrm{CO}$ attainments with target values are shown in Fig. 5.

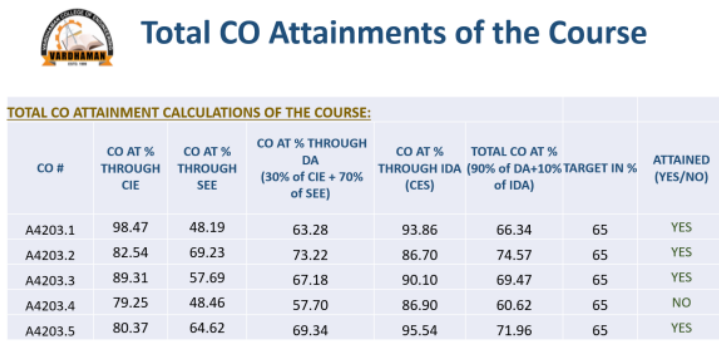

Fig. 4 Total CO Attainments of the BEE Course

$\mathrm{CO}$ attainment for the course Basic Electrical Engineering is given as an illustrative example. Likewise, the CO attainment for all courses of a particular batch is calculated. The CO attainment of the first semester is depicted in the Fig. 6. It is evident that $\mathrm{CO} 4(\mathrm{~A} 4203.4)$ is not attained where as other COs got attained. The reasons behind nonattainment of $\mathrm{CO} 4$ are discussed in section 7. The total number of $\mathrm{COs}$ and its attainment in Electrical and Electronics Engineering program for a particular batch is calculated and is shown in the Fig. 7.

\section{CO-PO Mapping (Course Articulation Matrix) METHODOLOGY}

CO of a particular course is mapped with the POs with a correlation level of 1, 2 and 3 (Slight or Low, Moderate or Medium, and Substantial or High respectively) through Course Articulation Matrix. CO-PO mapping or Course Articulation Matrix(CAM) is matrix having rows are COs of a course and columns are POs and PSOs which has a 
relation with COs. To obtain this correlation matrix the following steps are suggested:

Step1: Identify key elements of each PO and PSO

Step2: Identify key elements of each CO

Step3: Find the co-relation levels using key elements of POs/PSOs and COs.

With this method we can write proper justification to entries of correlation levels in CAM. This method is explained with example of one of the $\mathrm{CO}$ of BEE course as shown in Fig. 7. There is another method called Feel Satisfaction Method, where we get correlation levels, based feel factor without any analytical computations.

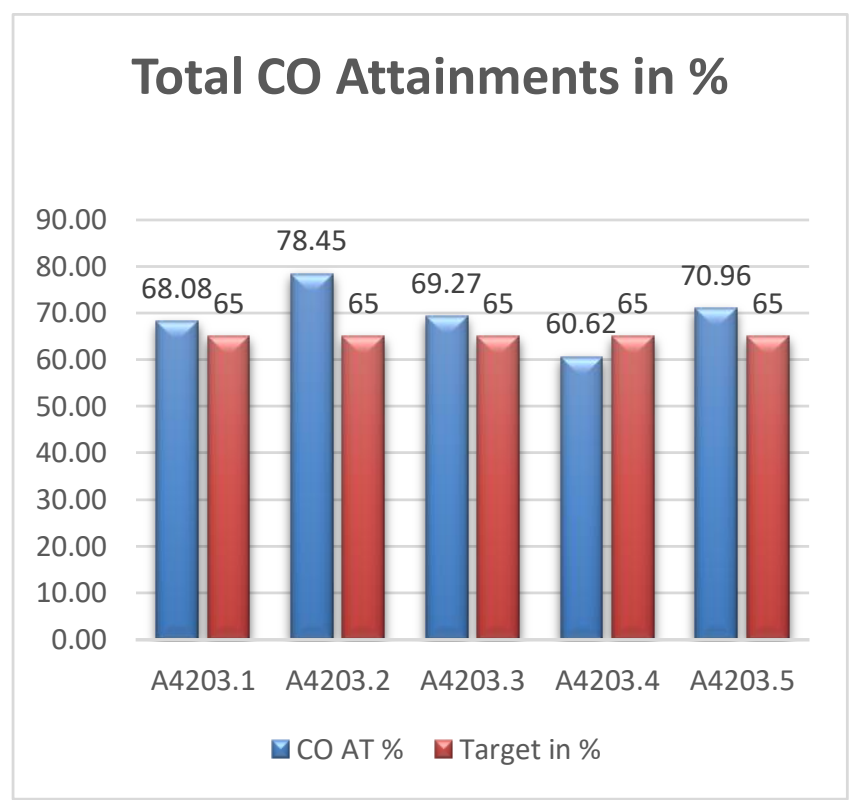

Fig. 4 CO Attainment Comparison with Target values

\begin{tabular}{|c|c|c|c|c|c|c|c|c|}
\hline \multicolumn{9}{|c|}{ Attainment of Course Outcomes of all the courses } \\
\hline \multicolumn{9}{|c|}{ TARGET: 65\% OF STUDNETS SHOULD GET MORE THAN OR EQUAL TO 60\% } \\
\hline Course & co\# & $\begin{array}{c}\text { Total co } \\
\text { AT } \\
\text { through } \\
\text { DA in \% }\end{array}$ & $\begin{array}{c}\text { Total Co } \\
\text { AT } \\
\text { through } \\
\text { IDA in } \\
\%\end{array}$ & $\begin{array}{c}90 \% \text { OF } \\
\text { Total co } \\
\text { AT } \\
\text { through } \\
\text { DA }\end{array}$ & $\begin{array}{l}10 \% \text { OF } \\
\text { Total co } \\
\text { AT } \\
\text { through } \\
\text { IDA }\end{array}$ & \begin{tabular}{|c|} 
Total CO \\
AT \\
through \\
DA $\underline{\varepsilon}$ \\
IDA in \\
$\%$ \\
\end{tabular} & \begin{tabular}{|l} 
Target \\
AT in \%
\end{tabular} & $\begin{array}{c}\text { Co } \\
\text { Attained } \\
\text { (YES/NO) }\end{array}$ \\
\hline \multirow{5}{*}{ MATHEMATICS-I } & A4001.1 & 66.78 & 86.85 & 253.43 & 8.69 & 62.11 & 65 & No \\
\hline & A4001.2 & 72.79 & 84.63 & 65.51 & 8.46 & 73.97 & 65 & YES \\
\hline & A4001.3 & 71.37 & 84.81 & 64.23 & 8.48 & 72.72 & 65 & YES \\
\hline & A4001.4 & 59.93 & 84.81 & 53.94 & 8.48 & 62.42 & 65 & No \\
\hline & A4001.5 & 71.90 & 84.26 & 64.71 & 8.43 & 73.13 & 65 & YES \\
\hline \multirow{5}{*}{$\begin{array}{l}\text { TECHNICAL } \\
\text { ENGLISH }\end{array}$} & \begin{tabular}{|l|} 
A4005.1 \\
\end{tabular} & 67.41 & 73.52 & 59.34 & 7.35 & 66.69 & 65 & YES \\
\hline & \begin{tabular}{|l} 
A4005.2. \\
\end{tabular} & 66.29 & 78.15 & 67.29 & 7.81 & 75.11 & 65 & YES \\
\hline & A4005.3 & 65.70 & 84.26 & 61.09 & 8.43 & 69.51 & 65 & YES \\
\hline & \begin{tabular}{|l|l} 
A4005.4 \\
\end{tabular} & 67.71 & 86.85 & 57.69 & 8.69 & 66.37 & 65 & YES \\
\hline & \begin{tabular}{|l|l} 
A4005.5 \\
\end{tabular} & 70.01 & 84.81 & 53.28 & 8.48 & 61.76 & 65 & YES \\
\hline \multirow{5}{*}{$\begin{array}{l}\text { PROBABILITY } \\
\text { THEORY AND } \\
\text { NUMERICAL } \\
\text { METHODS }\end{array}$} & \begin{tabular}{|l|l} 
A4004.1 \\
\end{tabular} & 59.34 & 86.85 & 59.34 & 8.69 & 68.02 & 65 & $\begin{array}{l}\text { YES } \\
\end{array}$ \\
\hline & \begin{tabular}{|l} 
A4004.2 \\
\end{tabular} & 67.29 & 84.81 & 67.29 & 8.48 & 75.78 & 65 & YES \\
\hline & \begin{tabular}{|l|l} 
A4004.3 \\
\end{tabular} & 61.09 & 78.15 & 61.09 & 7.81 & 68.90 & 65 & $\begin{array}{l}\text { YES } \\
\end{array}$ \\
\hline & \begin{tabular}{|l|l|} 
A4004.4 \\
\end{tabular} & 57.69 & 86.85 & 57.69 & 8.69 & 66.37 & 65 & YES \\
\hline & \begin{tabular}{|l|l} 
A3004.5 \\
\end{tabular} & 53.28 & 84.81 & 53.28 & 8.48 & 61.76 & 65 & YES \\
\hline \multirow{5}{*}{$\begin{array}{c}\text { BASIC } \\
\text { ELECTRICAL } \\
\text { ENGINEERING }\end{array}$} & A4203.1 & 63.28 & 93.86 & 56.95 & 9.39 & 66.34 & 65 & YES \\
\hline & A4203.2 & 73.22 & 86.70 & 65.90 & 8.67 & 74.57 & 65 & YES \\
\hline & A4203.3 & $\begin{array}{l}67.18 \\
\end{array}$ & 90.10 & 60.46 & 9.01 & 699.47 & 65 & $\begin{array}{l}\text { YES } \\
\end{array}$ \\
\hline & A4203.4 & 57.70 & 86.90 & 51.93 & 8.69 & 60.62 & 65 & No \\
\hline & A4203.5 & (69.34 & $\begin{array}{l}95.54 \\
\end{array}$ & (62.41 & 9.55 & 71.96 & 65 & YES \\
\hline
\end{tabular}

Fig. 5 CO Attainments of all the Courses

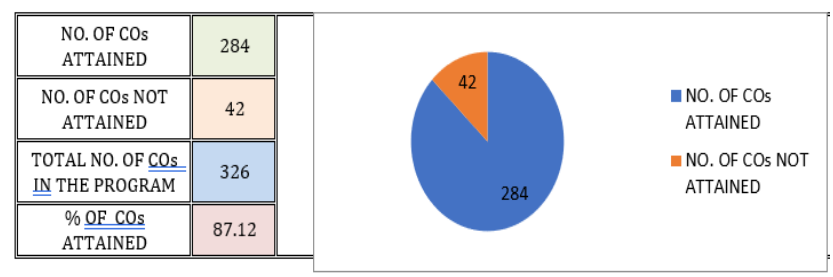

Fig. 6 Status of CO Attainments of the Program

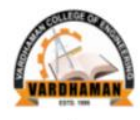

\section{CO-PO Mapping}

CO2(A4203.2): Analyze electrical circuits using nodal and $n$ analysis

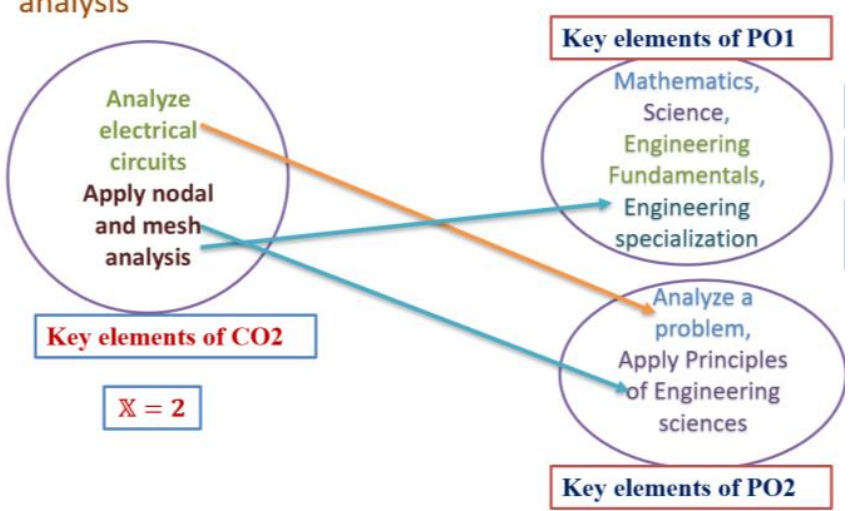

Fig. 7 CO-PO Mapping Methodology

\section{PO Attainment Computations of BEE Course}

PO attainments are obtained using $\mathrm{CO}$ attainments and $\mathrm{Co}-$ PO Mapping(CAM). PO1 attainment computations of BEE 
course is shown in Fig. 7 based on $\mathrm{CO}$ attainments and $\mathrm{CO}$ PO mapping.

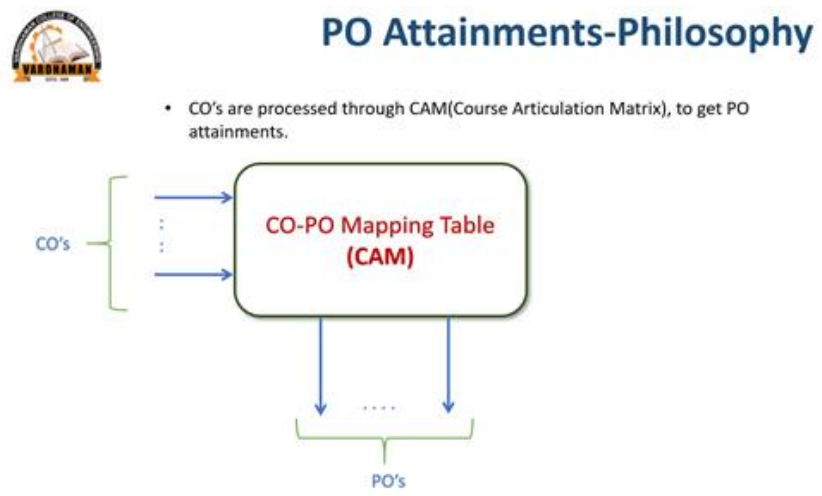

Fig. 8 CO-PO Mapping Philosophy

PO1 attainment computations of BEE course is shown in Fig. 9 based on $\mathrm{CO}$ attainments and CO-PO mapping.
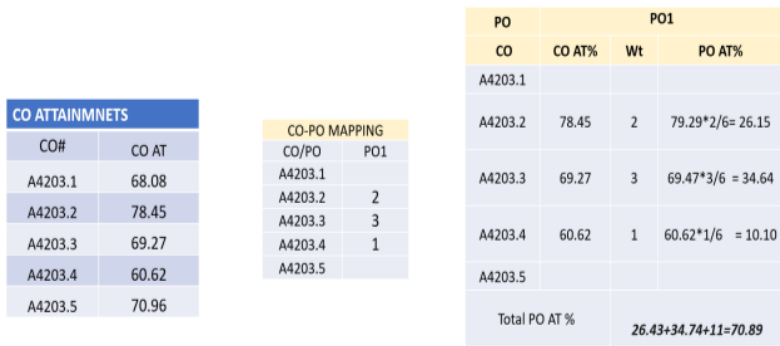

Fig. 9 Computation of PO1 Attainments of BEE Course

Likewise, PO and PSO attainment calculations is done for all the courses in a program. This type of Assessment is called as Direct Assessment. Indirect assessment of POs and PSOs is done using Student Exit Survey, Co-curricular and Extra-curricular activities mapped with the corresponding POs and PSOs. Attainments of POs and PSOs through Indirect assessment is shown in Table 6. Comparison of Technical POs and PSOs attainments and Non-Technical POs attainments with respective target values are shown Fig. 10 and Fig. 11 respectively.

Table 7. Attainments of POs Through IDA in \%

\begin{tabular}{|c|c|c|c|c|}
\hline PO \# & $\begin{array}{c}\text { Student } \\
\text { Exit } \\
\text { Survey }\end{array}$ & $\begin{array}{c}\text { Co- } \\
\text { Curricular } \\
\text { Activities }\end{array}$ & $\begin{array}{c}\text { Extra- } \\
\text { Curricular } \\
\text { Activities }\end{array}$ & $\begin{array}{c}\text { Total PO } \\
\text { AT\% } \\
\text { Through } \\
\text { IDA }\end{array}$ \\
\hline PO1 & 71.36 & & & 71.36 \\
\hline PO2 & 72.11 & & & 72.11 \\
\hline PO3 & 79.17 & & & 79.17 \\
\hline
\end{tabular}

\begin{tabular}{|c|c|c|c|c|} 
PO4 & 75.00 & & & 75.00 \\
\hline PO5 & 71.67 & & & 71.67 \\
\hline PO6 & 77.08 & 86.15 & 70.77 & 78.00 \\
\hline PO7 & 74.58 & 82.05 & 81.03 & 79.22 \\
\hline PO8 & 82.55 & 97.03 & 81.03 & 86.87 \\
\hline PO9 & 75.83 & 97.03 & 81.03 & 84.63 \\
\hline PO10 & 78.33 & 97.03 & 62.56 & 79.31 \\
\hline PO11 & 73.19 & 85.13 & 93.33 & 83.88 \\
\hline PO12 & 72.92 & 92.31 & 70.77 & 78.67 \\
\hline PSO1 & 68.56 & & & 68.56 \\
\hline PSO2 & 65.26 & & & 65.26 \\
\hline
\end{tabular}

Table 8. Total PO \& PSO Attainments of the Program

Total PO and PSO Attainments in \%

\begin{tabular}{|c|c|c|c|c|c|}
\hline PO \# & $\begin{array}{c}\text { PO } \\
\text { AT } \\
\text { Throu } \\
\text { gh DA }\end{array}$ & $\begin{array}{c}\text { PT } \\
\text { Through } \\
\text { IDA }\end{array}$ & $\begin{array}{c}\text { Total } \\
\text { PO } \\
\text { ATo } \\
\mathbf{9 0} \% \\
\text { DA+10 } \\
\text { \% IDA }\end{array}$ & $\begin{array}{c}\text { Target } \\
\text { in \% }\end{array}$ & $\begin{array}{c}\text { PO } \\
\text { Attained } \\
\text { (YES/NO } \\
\text { ) }\end{array}$ \\
\hline PO1 & 71.29 & 71.36 & 71.29 & 70 & YES \\
\hline PO2 & 72.78 & 72.11 & 72.71 & 70 & YES \\
\hline PO3 & 73.44 & 79.17 & 74.02 & 70 & YES \\
\hline PO4 & 78.05 & 75.00 & 77.74 & 70 & YES \\
\hline PO5 & 79.87 & 71.67 & 79.05 & 70 & YES \\
\hline PO6 & 73.72 & 78.00 & 74.15 & 70 & YES \\
\hline PO7 & 85.14 & 79.22 & 84.55 & 70 & YES \\
\hline PO8 & 77.73 & 86.87 & 78.64 & 70 & YES \\
\hline PO9 & 95.29 & 84.63 & 94.22 & 70 & YES \\
\hline PO10 & 90.67 & 79.31 & 89.53 & 70 & YES \\
\hline PO11 & 81.00 & 83.88 & 81.28 & 70 & YES \\
\hline PO12 & 95.14 & 78.67 & 93.50 & 70 & YES \\
\hline PSO1 & 74.25 & 68.56 & 73.68 & 70 & YES \\
\hline PSO2 & 73.14 & 65.26 & 72.35 & 70 & YES \\
\hline
\end{tabular}




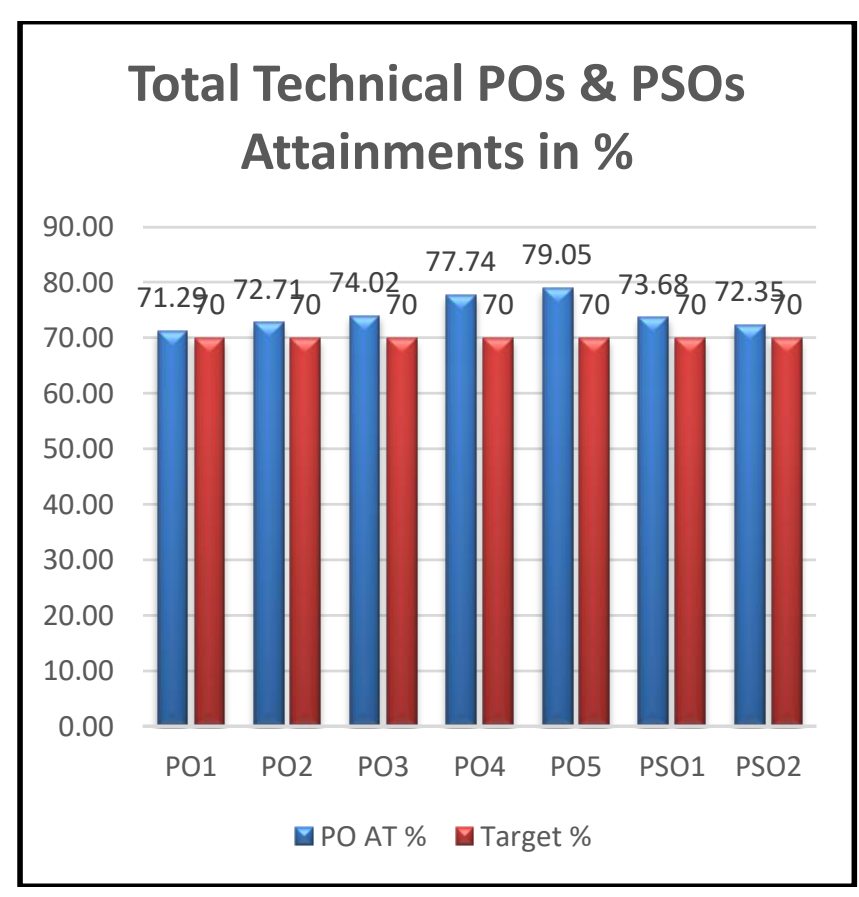

Fig. 10 Comparison of Technical POs and PSOs Attainments with target values

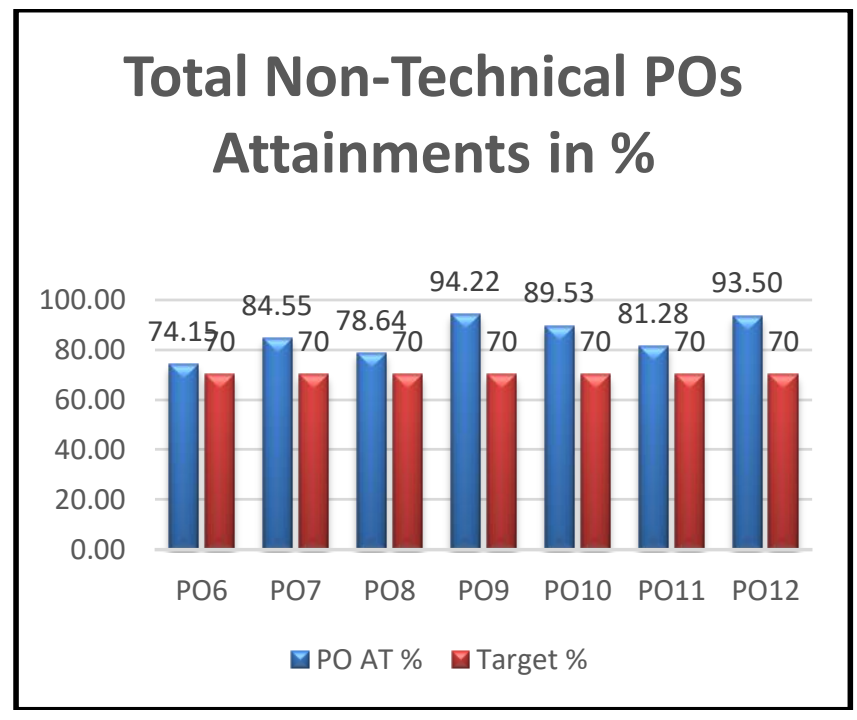

Fig. 11 Comparison of Non-Technical POs attainments with target values

\section{CONTINUOUS QUALiTY IMPROVEMENT}

The program must evaluate the attainment of student outcomes, these evaluations must be used as inputs for continuous quality improvement. Therefore, by closing the loop at course level, program level and Institute level, we ensure continuous quality assurance for stake holders. Other available information may also be used to assist in the continuous improvement of the program.
A. CO attainments level comparisons and action taken for improvement

The attainment levels of each COs of the course are compared with target levels and the observations are recorded. The outcome of $\mathrm{CO} 4$ is about analysis of solution of transient networks, that requires strong knowledge in differential equations and Laplace transforms. It is observed that the students of the respective class are not good in in differential equations and Laplace transforms. It is suggested that mathematical background of class students need to be identified and special classes can be arranged to improve mathematical fundamentals.

B. PO/PSO attainments level comparisons and action taken for improvement

The attainment levels of each POs and PSOs of the program are compared with target levels and the observations are recorded. If any PO is attained, then it is suggested to increase the target level or strengthen the assessment tools. If any PO is not attained, the attainment gap is identified, then course wise observations are made, and the actions taken are recommended.

\section{Concluding Remarks}

In this paper, computations of the attainment of COs of BEE course and POs, PSOs of the program. Results and discussions are done on the attainment of COs of different courses and suggestions for the courses which fail to attain the target has been discussed. A sample of CO-PO attainment calculation for the course Basic Electrical Engineering offered for BTech I Year students has been discussed. Continuous quality improvement is discussed and suggested few improvements.

\section{Acknowledgement}

The authors wish to express their gratitude to the Management, Principal, and other faculty of Vardhaman College Engineering, Hyderabad, for the encouragement and valuable suggestions in bringing out this paper.

\section{References}

[1] http://www.nbaind.org/files/evaluationguidelinestier-ii-v0.pdf

[2] http://www.nbaind.org/files/obe-and-nba accreditation.pdf

[3] Izham Zainal Abidinet. Al,(2009) Assessing the attainment of course outcomes for an engineering course, Proceedings of the 2nd International Conference of Teaching and Learning (ICTL 2009), Malaysia. 
[4] Richard M Fedler, (2003) Designing and Teaching Courses to Satisfy the ABET Engineering Criteria, J. of engineering Education, 92, 2003.

[5] Karen M. Bursic,(2011) Improving Student Attainment of ABET Outcomes Using ModelEliciting Activities (MEAs), American Society for Engineering Education, 2011.

[6] M.S. Jaafar, N. K. Nordin, R. Wagiran, A. Aziz,M.J.M.M. Noor, M.R. Osman, J.Noorzaei and F.N.A. Abdulaziz, (2008) Assessment Strategy for an Outcome Based Education, International Conference on Engineering Education, July 2008.

[7] Kavitha, A, Immanuvel Arokia James, K, Harish, K A., and Rajamani.V.,(2017) An Empirical Study on Assessment and Attainment Method of Course Outcome and Programme Outcome for NBA Tier II Accreditation in Engineering Colleges through Outcome Based Education (OBE), Special issue on Green Computing and Networking in International Journal of Pure Applied Mathematics, Academic Publications Ltd., Bulgaria, Vol 117, No 22, pp. 25 28, Dece 2017, pISSN 1311-8080.

[8] Surendar Rawat, Shruti Karkare,(2015) An Empirical study on Assessment of $\mathrm{CO}$ attainment for a Diploma Course, IJECET, vol 6, no.2, pp. 0612, 2015.

[9] Geeta Deswal, Kumar Guarve, Ashwani Dhingra, Priyanka Kriplani, Bhawna Chopra and Rameshwar Dass,(2016) Assessment Method for Course Outcomes and Program Outcome, vol 2, no3, pp.5868, Academica Editores: ActaVelit, 2016.

[10] Zamri Mohamed, Mohd YusofTaib, M.S. Reza, (2010) Assessment Method for Course Outcome and Program Outcome in Outcome Based Education (OBE), Proc. of Malaysian Technical Universities Conference on Engineering and Technology, 2010.

[11] PritiKudal, Vishakha Pawar, Deepika Thakare, Bhakti Nandurdikar,(2017) A Tool for Course Outcome Attainment, International Journal of Technical Research and Applications, vol 5, no 1, pp: 38-42, 2017.

[12] Abhishek Koshti, Durvesh Kadole, Navnath Kamble, Pushkar Gadgil, LaxmiBewoor, (2016) Knowledge Based Tool for PO Attainment, Special issue on Int. Journal of Research in Advent Technology, pp:122-126, 2016. 